sciendo Порівняльна професійна педагогіка 8(2)/2018 Comparative Professional Pedagogy 8(2)/2018

DOI: $10.2478 /$ rpp-2018-0013

Doctor of Science in Pedagogy, Full Professor, NATALYA BIDYUK Khmelnytskyi National University, Ukraine Address: 11 Instytutska St., Khmelnytskyi, 29016, Ukraine E-mail: biduknm@ukr.net

Postgraduate Student, HALYNA OLESKOVA Khmelnytskyi National University, Ukraine Address: 11 Instytutska St., Khmelnytskyi, 29016, Ukraine E-mail: grugorivna.galuna@gmail.com

\title{
CURRENT STATUS AND PROSPECTS FOR DEVELOPMENT OF NURSING PROFESSIONS IN GERMANY
}

\begin{abstract}
This article deals with the study of current status and prospects for development of nursing professions in Germany. It outlines the classification of "Healthcare Professions" and "Healthcare and Nursing Professions", which are also identified with "Nursing Professions". Besides, such concepts as "nursing", "qualification level 2", "qualification level 3", "job vacancy duration" have been defined here. It describes more detailed the second and third qualification levels of nursing professions according to the German Classification of Occupations of 2010. In addition, the article highlights the problem of shortage of nursing personnel in Germany at the level of skilled workers and specialists. Within this paper, the authors analyze the actual data on the shortage of German nursing personnel in healthcare and nursing and geriatric nursing at the level of skilled workers and specialists. Special attention in the paper is paid to the fact that Germany as a member of International Council of Nurses and World Health Organisation, takes part in a worldwide care campaign "Nursing Now", that was launched on 27 February 2018. It is designed for three years and aims to achieve many goals by the end of 2020: strengthen the role and potential of the nursing professions, thereby improving the health of the world's population. Much attention in the article is paid to the description of the new German Nursing Professions Act of 17 July 2017 that will enter into force on 1 January 2020. That is why rather perspective is further studies on the peculiarities of professional training of German nursing personnel before and after 1 January 2020.

Keywords: Germany, nursing personnel, nursing professions, nursing shortage, qualification level, skilled workers, specialists, statistical data.

\section{INTRODUCTION}

Nursing is a unique and at the same time versatile professional activity that offers a wide range of opportunities for career development and professional growth of nursing personnel. Nursing aims to preserve, restore or empower the self-reliance of the individuals, to deal with the limitations of their own lifestyle and to discover the new quality of life. Upon obtaining the nursing education, nursing personnel expects a guaranteed job, as the demand for the profession of highly skilled nursing personnel is only increasing due to demographic changes in society. Nursing professions will never "go out of fashion" in
\end{abstract}


sciendo Порівняльна професійна педагогіка 8(2)/2018

Comparative Professional Pedagogy 8(2)/2018

society, as people will always need qualified nursing care in different living situations and at any stage of their lives (Hessisches Ministerium für Soziales und Integration, 2018).

International Council of Nurses states that "nursing encompasses autonomous and collaborative care of individuals of all ages, families, groups and communities, sick or well and in all settings. Nursing includes the promotion of health, prevention of illness, and the care of ill, disabled and dying people. Advocacy, promotion of a safe environment, research, participation in shaping health policy and in patient and health systems management, and education are also key nursing roles" (International Council of Nurses, 2018).

It should be mentioned that Germany is a member of International Council of Nurses (ICN) and World Health Organisation (WHO). ICN and WHO have jointly launched on 27 February 2018 a worldwide care campaign "Nursing Now". It is designed for three years and aims to achieve many goals by the end of 2020: strengthen the role and potential of the nursing professions, thereby improving the health of the world's population. It also aims to improve perceptions of nurses, enhance their influence and maximise their contributions to ensuring that everyone everywhere has access to health and healthcare. On the one hand, one wants to exert influence on politicians and their strategies, on the other hand, it also supports nurses in directing, learning and building a global movement. Nursing Now will run to the end of 2020 - the 200th anniversary of Florence Nightingale's birth and a year when nurses will be celebrated worldwide (DBfK, 2018; Nursing Now, 2018).

\section{THE AIM OF THE STUDY}

The aim of this article is to define the current status of German nursing professions by means of a comparative analysis of statistical data. Besides, it aims to describe the prospects for development of nursing professions in Germany.

\section{THEORETICAL FRAMEWORK AND RESEARCH METHODS}

Theoretical framework of the research is, first of all, the regulations of the new German Nursing Professions Act of 17 July 2017, one of the sections of the German Coalition Agreement of 2018, information from the German Classification of Occupations from 2010, statistical data published by the Federal Employment Agency, materials of the German Professional Nursing Association and International Council of Nurses.

One of the research methods used in this paper is a theoretical analysis of normative legislative documents, scientific literature, electronic resources on the problem under study. Besides, we have conducted a comparative analysis of statistical data on nursing shortage, contained in this specialised sources. Such methods as synthesis, generalisation, and systematisation of data analysed were also used here.

RESULTS

First of all, it should be noted that the professions of nursing personnel in Germany are state-recognised and regulated professions. They are classified differently, but are commonly grouped into the "Healthcare Professions" ("Gesundheitsfachberufen") and "Healthcare and Nursing Professions" ("Gesundheits- und Pflegeberufe"), which are also identified with "Nursing Professions" ("Pflegerische Berufe", "Pflegeberufe"), cover all activities related to direct patient care or nursing. In addition, the functions of this group of professions include all activities in the field of therapy in the context of the prevention, detection and treatment of diseases. Thus, the professions of nursing personnel in Germany belonging to a group called "nursing professions", unlike in Ukraine, include the profession of a midwife $(\mathrm{m} / \mathrm{f})$ (Hebamme/Entbindungspfleger), who mainly works in maternity units at hospitals, in midwives' practices and at maternity homes. Besides, the peculiarity of classification of 
nursing professions lies in distinguishing between male and female genders (Bundesagentur für Arbeit, 2010; 2013; 2018).

According to the definition used in Classification of Occupations of 2010, professions are classified according to the level of requirements or the complexity of their activities. A distinction is made between four requirement levels and complexity levels. Thus, the professions of nursing personnel at the qualification levels of occupations are divided into the following groups: 1st qualification level - level of helpers and trainees (e.g., healthcare assistant), 2nd qualification level - level of skilled workers (e.g., health and nursing professional), 3rd qualification level - level of specialists (e.g., Specialist nurse $(\mathrm{m} / \mathrm{f})$ - operation/endoscopic surgery), 4th qualification level - level of experts (e.g., Nursing service manager) (Figure 1) (Bundesagentur für Arbeit, 2010; 2017).

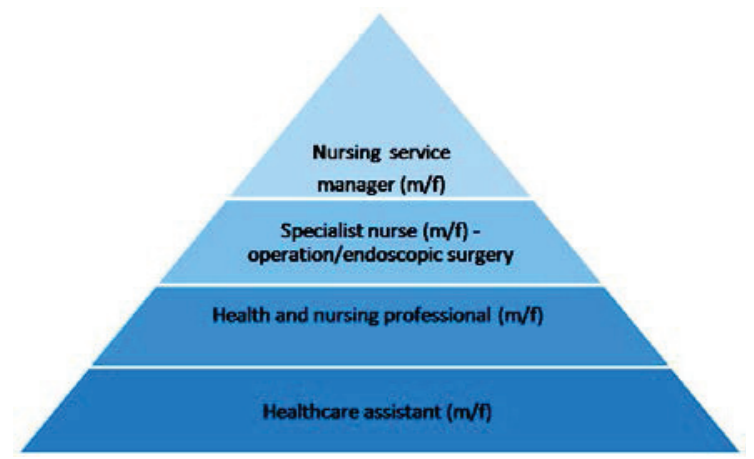

Fig. 1. The nursing professions at the qualification levels of occupations

According to the Classification of Occupations of 2010 (Klassifikation der Berufe Kldb-10), most nursing professions in Germany meet the second and third qualification levels of professions in Germany. Therefore, for further use in the paper of the concepts "qualification level 2" and "qualification level 3", we will find out the essence of these concepts. "Qualification level 2 - Skilled worker - corresponds to a professionally oriented activity that requires at least two years of vocational training or a similar qualification. Qualification level 3 - Specialist - comprises occupations whose practitioners require specialist knowledge and skills that usually necessitate training as a master craftsman or technician or an equivalent technical college or university degree" (Bundesagentur für Arbeit, 2010; 2017).

Let us consider in more detail the second and third qualification levels of nursing professions. The professions of nursing personnel corresponding to the second qualification level of occupations are divided into the groups called "Health and Nursing Professions" ("Berufe in der Gesundheits- und Krankenpflege") and "Geriatric Nursing Professions" ("Berufe in der Altenpflege"). The group "Health and Nursing Professions" embrace registered general nurse or health and nursing professional $(\mathrm{m} / \mathrm{f})$ (Gesundheits- und Krankenpfleger/Gesundheits- und Krankenpflegerin) and children's nurse or health and paediatric nurse (m/f) (Gesundheits- und Kinderkrankenpfleger/Gesundheits- und Kinderkrankenpflegerin). The group "Geriatric Nursing Professions" includes geriatric nurse $(\mathrm{m} / \mathrm{f})$ (Altenpfleger/Altenpflegerin). The professions of nursing personnel at the third qualification level of occupations are divided into the following groups: "Specialised Health and Paediatric Nursing Professions" ("Berufe in der Fachkinderkrankenpflege"), 
sciendo Порівняльна професійна педагогіка 8(2)/2018

Comparative Professional Pedagogy 8(2)/2018

"Specialised Health and Nursing Professions" ("Berufe in der Fachkrankenpflege"), "Specialised Geriatric Nursing Professions" ("Berufe in der Altenpflege") (Bundesagentur für Arbeit, 2010; 2017; 2018).

It is advisable to pay attention to the fact that demographic change is becoming increasingly visible in Germany. As a result, almost all German Länder are faced with a shortage of nursing personnel, despite the rising number of doctors in private practice and increasing employment of nursing personnel in healthcare and nursing professions. There is no doubt that at the level of skilled workers (Fachkräfte) and specialists (Spezialisten), there is a shortage of nursing personnel in healthcare and nursing (Gesundheits- und Krankenpflege) and geriatric nursing (Altenpflege) (Arbeitsgemeinschaft der Mitarbeitervertretungen, 2017, p. 15).

As the proportion of older people in German society increases, there is a wider need for inpatient and outpatient care services. Hospitals, nursing homes and other care providers are finding it harder and harder to recruit and retain skilled nursing personnel. In light of far-reaching demographic change, the demand for nursing personnel in geriatric nursing is rapidly increasing. It is expected that by 2050 , more than twice as many people will be in need of care. This means that securing an adequate number of skilled nursing personnel is an important challenge for Germany. In order to face up to this challenge, a number of different strategies have been devised. These include, for example, the reform of nursing training which is to be implemented by 2020 , as well as the recruitment of nursing professionals from abroad (Make it in Germany, 2018).

Any individuals wishing to work in nursing, for example, as a health and nursing professional in Germany without any restrictions requires a state licence. They may also apply for a licence if they have foreign qualifications. The competent authorities review their qualifications for equivalence with corresponding German qualifications. A licence can be issued if equivalence of qualifications has been determined. Citizens of the EU or the European Economic Area wishing to work in Germany on a temporary or occasional basis do not require a state licence. However, they do have to report their employment to the competent authorities (Make it in Germany, 2018).

Within this paper, we would like to analyse the actual data on nursing shortage at the level of skilled workers and specialists. To comprehend and further use of the term "job vacancy duration" in the paper, we will clarify the essence of this concept. If job vacancy is available, job vacancy duration is calculated as the difference between the statistical deadline and the earliest potential date of job employment. Job vacancy duration is zero days if the date of job employment coincides with the statistical deadline. Then, the job is considered to be "not vacant" (Bundesagentur für Arbeit, 2010, p. 55).

According to the statistical data published by the Federal Employment Agency (DIW Berlin, 2014; Nationwide Shortage of Nursing Personnel, 2017; Skills Gap Analisis, 2016; WELT, 2014), analysed from June in the previous year till May in the current year, average job vacancy duration (in days) is as follows (Figure 2) (Arbeitsgemeinschaft der Mitarbeitervertretungen, 2017; Bundesagentur für Arbeit, 2016; das Statistik-Portal, 2017; Deutsches Institut für Wistschaftsforschung, 2014; Welt Digital Zeitung, 2014).

According to the Skills Gap Analysis (Fachkräfteengpassanalyse) published by Federal Employment Agency, in June 2017, for every 100 job vacancies the number of unemployed at the level of skilled workers was only 22 candidates in the field of geriatric nursing (Altenpflege) and 45 candidates in the field of healthcare and nursing (Gesundheits- und Krankenpflege). 
sciendo Порівняльна професійна педагогіка 8(2)/2018

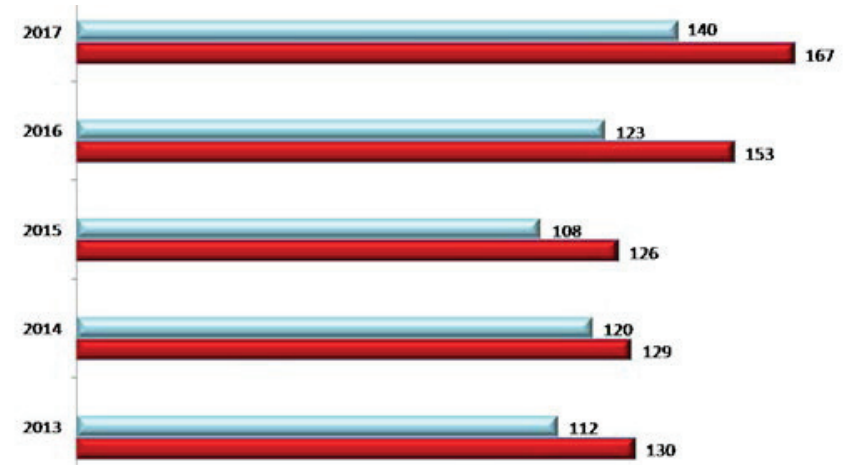

Fig. 2. Average job vacancy duration at the level of skilled workers and specialists:

Skilled Workers and Specialists in Healthcare and Nursing

Skilled Workers and Specialists in Geriatric Nursing

According to the Skills Gap Analysis (Fachkräfteengpassanalyse) published by Federal Employment Agency, in June 2017, for every 100 job vacancies the number of unemployed at the level of skilled workers was only 22 candidates in the field of geriatric nursing (Altenpflege) and 45 candidates in the field of healthcare and nursing (Gesundheits- und Krankenpflege). At the same time, at the third qualification level, the number of unemployed for every 100 job vacancies was as follows: the area of specialised geriatric nursing (Altenpflege - Spezialtätigkeit) - 32 candidates, the field of specialised nursing (Fachkrankenpflege) -28 candidates, healthcare and nursing, emergency services, obstetrics (Gesundheits- und Krankenpflege, Rettungsdienst, Geburtshilfe) - 23 candidates (Figure 3, Figure 4) (Institut der deutschen Wirtschaft, 2018; Make it in Germany, 2018).

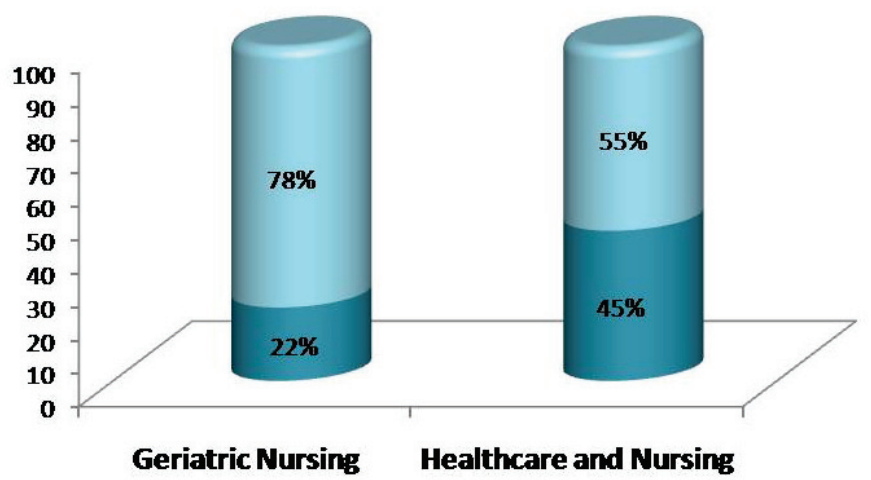

Fig. 3. Shortage of skilled workers

Practical activities of health and nursing professionals, health and paediatric nursing personnel in Germany are now regulated by "Nursing Act" ("Krankenpflegegesetz") of 16 July 2003 (last amended on 17 July 2017). Practical activities of geriatric nursing personnel are now regulated by the "Geriatric Nursing Act" ("Altenpflegegesetz") of 17 November 2000 (last amended on 17 July 2017). These acts will be in force until 31 January 2019. 


\section{S sciendo Порівняльна професійна педагогіка 8(2)/2018}

Comparative Professional Pedagogy 8(2)/2018
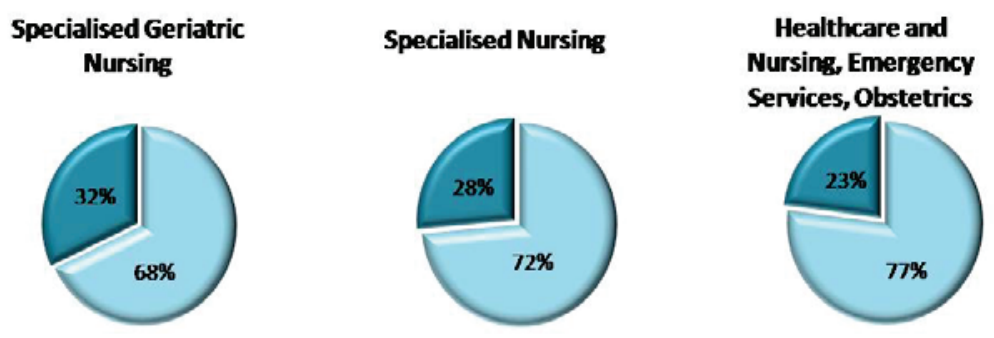

Fig. 4. Shortage of specialists

Creating a new general nursing profession from the existing three independent nursing professions in geriatric nursing, healthcare and nursing, healthcare and paediatric nursing met with considerable resistance, especially in the care of the elderly. Later the coalition parties have agreed in the spring of 2017 on a political compromise on the reform of the nursing profession. Despite some criticism, the German Bundestag, with the consent of the Federal Council of Germany (Bundesrat), finally adopted on 17 July 2017 the new German Nursing Professions Act (Pflegeberufegesetz, PflBG) (Bündnis für Altenpflege, 2017; DBfK, 2018).

On 1 January 2020, the new German Nursing Professions Act of 17 July 2017 will enter into force. This means that apprentices who start training in nursing before 1 January 2020 will be subject to different rules and regulations than those who start training after 1 January 2020. The new German Nursing Professions Act that was preceded by long-term discussion is transforming some fundamental aspects of nursing training and the fields of work of nursing personnel.

All applicants starting to train as skilled nursing professionals after 1 January 2020 will undergo two years of general nursing training. In the third year of training, apprentices will either continue general training to become general nurses - skilled nursing professionals (Pflegefachfrau/Pflegefachmann) or specialise to become a geriatric nurse or a paediatric nurse. Besides, they can choose the training option that exactly fits their needs. Another plus of this general nursing training is that it is recognised across the EU or the European Economic Area, giving individuals working in nursing even more job opportunities. The new nursing training programme will be completely free of charge, and apprentices will receive adequate remuneration. Nursing professionals will have better opportunities for finding work, changing jobs, being promoted and for personal development in all areas of nursing care (BMFSFJ, 2018; DBfK, 2018; Make it in Germany, 2018) (Fig. 5).

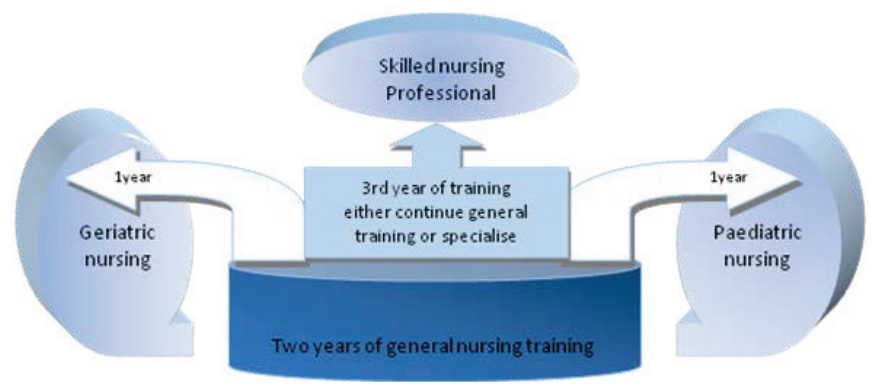

Fig. 5. General nursing training after 1 January 2020 
In the future, it is planned in Germany "to attach great importance to attracting highly motivated and well-trained young people in the healthcare professions. For this, it is necessary to create attractive training opportunities. A great emphasis is placed on the implementing the Master Plan for Medical Studies 2020 with regard to the new regulation of study access, the strengthening of general medicine and the country doctor's rate. This includes more medical study places. New German coalition promises to reorganise and strengthen the training of healthcare professions as part of an overall concept" (CDU, 2018).

\section{CONCLUSIONS}

As the research results show, there is a considerable shortage of nursing personnel in Germany at the level of skilled workers and specialists especially in the field of geriatric nursing. In July 2017, Germany reformed the nursing training system to create a new general nursing profession from the existing three independent nursing professions in geriatric nursing, healthcare and nursing, healthcare and paediatric nursing, and make the nursing profession more attractive. On 1 January 2020, the new German Nursing Professions Act (Pflegeberufegesetz, PflBG) of 17 July 2017 will enter into force. We found out that the adoption of the new law was preceded by long-term discussion in German society, but later a compromise was found. New German coalition promise to reorganise and strengthen the training of healthcare professions as part of an overall concept. We consider it rather perspective to further study the peculiarities of the professional training of Germany nursing personnel before and after 1 January 2020.

\section{REFERENCES}

1. Arbeitsgemeinschaft der Mitarbeitervertretungen. (2017). Bundesweiter Personalmangel in der Pflege. Retrieved from https://ag-mav.org/2017/07/27/ bundesweiter-personalmangel-in-der-pflege/.

2. Arbeitsgemeinschaft der Mitarbeitervertretungen. (2017). Seiten aus BA-FKEngpassanalyse-2017-06. Retrieved from https://ag-mav.org/seiten-aus-ba-fk-engpassanalyse-2017-06/.

3. Bundesagentur für Arbeit. (2018). Beruf aktuell 2017/2018 - Lexikon der Ausbildungsberufe. Retrieved from https://www3.arbeitsagentur.de/web/wcm/idc/groups/ public/ documents/webdateimdaw/mtm5/ edisp/16019022dstbai390559.pdf?_ba.sid=L6019022DS TBAI390562.

4. Bundesagentur für Arbeit. (2018). Berufenet - Berufsinformationen einfach finden. Retrieved from https://berufenet.arbeitsagentur.de/ berufenet/faces/index; BERUFENET JSESSIONID=nPJeWD9IV4LrESmIinxdgrWnfPmNt9DfkSmRYRIrXP1CsmOlAvzF!970730275?path=null.

5. Bundesagentur für Arbeit. (2016). Der Arbeitsmarkt in Deutschland Fachkräfteengpassanalyse. Retrieved from http://brackenheimer.de/wp-content/uploads/2016/ 09/BA-FK-Engpassanalyse-2016-06.pdf.

6. Bundesagentur für Arbeit. (2010). Gesamtglossar der Fachstatistiken der Bundesagentur für Arbeit (BA). Retrieved from https://statistik. arbeitsagentur.de/Statischer Content/Grundlagen/Glossare/Generische-Publikationen/Gesamtglossar.pdf.

7. Bundesagentur für Arbeit. (2010). KldB2010-Printversion-Band1.pdf. Retrieved from https://statistik.arbeitsagentur.de/Statischer-Content/Grundlagen/Klassifikation-der-Berufe/KldB2010/Printausgabe-KldB-2010/Generische-Publikationen/KldB2010Printver-sion-Band1.pdf. 
sciendo Порівняльна професійна педагогіка 8(2)/2018

Comparative Professional Pedagogy 8(2)/2018

8. Bundesagentur für Arbeit. (2013). Steckbrief-GesundheitsPflegeberufe.pdf. Retrieved from https://statistik.arbeitsagentur.de/ Statischer-Content/Grundlagen/Klassifikation-der-Berufe/KldB2010/Arbeitshilfen/Berufsaggregate/Generische-

Publikationen/Steckbrief-Gesund-heitsPflegeberufe.pdf.

9. Bundesagentur für Arbeit. (2017). Whitelist - Immigration into recognized occupations. Retrieved from https://www3.arbeitsagentur.de/web/wcm/idc/groups/public/ documents/webdatei/mdaw/mta4/ edisp/L6019022DSTBAI777367.pdf.

10. Bundesministerium für Familie, Senioren, Frauen und Jugend. (2018). BMFSFJ - Weiterentwicklung der Pflegeberufe. Retrieved from https://www.bmfsfj.de/ $\mathrm{bmfsfj} /$ themen/aeltere-menschen/altenpflegeausbildung/weiterentwicklung-pflegeberufe/ weiterentwicklung-der-pflegeberufe/77264.

11. Bündnis für Altenpflege. (2017). DKR-newsletter. Retrieved from http://www. aaa-deutschland.de/images/pdf/Buendnisschrift\%20Pruefsteine $\% 20$

PflegeberufereformG.\%2010-2017.

12. CDU. (2018). Koalitionsvertrag_2018.pdf. Retrieved from https://www. cdu.de/ system/tdf/media/dokumente/koalitionsvertrag_2018.pdf?file=1.

13. Das Statistik-Portal. (2017). Fachkräftemangel in Gesundheits- und Pflegeberufen Retrieved from https://de.statista.com/ infografik/11447/fachkraeftemangel-in-gesundheitsund-pflegeberufen/.

14. Deutscher Berufsverband für Pflegeberufe. (2018). DBfK-Inforeihe-Pflege berufegesetz.pdf. Retrieved from https://www.dbfk.de/media/ docs/download/Allgemein/ DBfK-Inforeihe-Pflegeberufegesetz.pdf .

15. Deutscher Berufsverband für Pflegeberufe. (2018). Nursing Now - globale Pflege-Kampagne gestartet - DBfK. Retrieved from https://www.dbfk.de/de/presse/ meldungen/2018/2329233840.php.

16. Deutsches Institut für Wirtschaftsforschung. (2014). DIW Berlin: Die Debatte über den Fachkräftemangel. Retrieved from https://www.diw.de/de/diw 01.c.434984. de/presse/diw_roundup/die_debatte_ueber_den_fachkraeftemangel.html.

17. Hessisches Ministerium für Soziales und Integration. (2018). Pflegerische Berufe. Retrieved from http://www.gesundheits-und-pflegeberufe.hessen.de/aw/home/ $\sim$ d/Pflegerische Berufe/.

18. Institut der deutschen Wirtschaft. (2018). Fachkraft verzweifelt gesucht Retrieved from https://www.iwd.de/arbeit-und-soziales/arbeitsmarkt/.

19. International Council of Nurses. (2018). Definition of Nursing. Retrieved from http://www.icn.ch/who-we-are/icn-definition-of-nursing/.

20. Make it in Germany. (2018). Nursing Professionals. Retrieved from http://www. make-it-in-germany.com/en/for-qualified-professionals/working/demanded-professions/nursing-professionals.

21. Nursing Now. (2018). Our aims for 2020. Retrieved from http://www.nursingnow.org/our-aims/.

22. WELT Digital Zeitung. (2014). Fachkräftemangel: Ärzte-Stellen bleiben 167 Tage lang unbesetzt. Retrieved from https://www.welt.de/ wirtschaft/article129937193/ Aerzte-Stellen-bleiben-167-Tage-lang-unbesetzt.html. 